\title{
Corruption perception and bilateral trade flows: Evidence from developed and developing countries
}

\author{
Putu Mahardika Adi Saputra \\ Department of Economics, University of Brawijaya, \\ Indonesia \\ putu@ub.ac.id \\ ORCID 0000-0002-6228-8500
}

\begin{abstract}
This study aims to examine the impact of corruption on bilateral trade flows in developed and developing countries by using an extension of the gravity panel model. The model reviews 30 countries among which 19 are developed countries and 11 are developing ones, during the period of 1995 2016. For the impact of corruption on export activities, it appears that domestic level of corruption has insignificant effect upon bilateral export in both developed and developing countries, but the asymmetric effect of the partner country's corruption level is significantly apparent in the case of export. Positive effect from low level of partner countries' corruption in raising bilateral export is found to be greater for developing countries than for developed ones. The effect of corruption on bilateral imports tend to be similar to bilateral exports, however, it has been also found that low domestic corruption level in the reporting countries will positively affect import activities and that fact becomes more apparent for developing countries.
\end{abstract}

Keywords: corruption, bilateral trade, gravity model, competitiveness.

JEL Classification: C33, D73, F14, O14.

\section{INTRODUCTION}

It has been acknowledged that bilateral trade could be used as one of country's economic vehicles while connecting to the global world (Pugel, 2016). Bilateral trade in the context of open economy brings opportunities for a country to grow and develop based on its national interests (Krugman et al., 2012). According to (Feenstra \& Taylor, 2014), bilateral trade provides countries with possibilities to expand to local markets via export activities and support the performance of domestic economy through optimal use of imported products (which are cheaper and/or better in quality). Fetahi-Vehapi et al. (2015) also noted that countries that are historically more active at international markets tend to be more productive than the ones producing commodities for domestic market only. 
Bilateral trade is closely related to industrialization process, technology transfer, capital accumulation, quality improvement of human resources, and institutional strengthening of a country (De Groot et al., 2005; Semancikova, 2016). In applied economics, lack of institutional quality has long been considered as one of the causes for economic inefficiency. Bandyopadhyay (2016) explains that differences in country's governance and institutional quality can cause differences in bilateral trade efficiency. Poor quality of institutions could also be a signal of rampant illegal activities and severity of corruption that trigger highcost economy in a country (Della Porta, 2000; Chang \& Chu, 2006; Habibov et al., 2017).

In principle, there are two opposing hypotheses regarding the impact of corruption activities on economic performance, namely,"sand the wheels" hypothesis and "grease the wheels" hypothesis. The "sand the wheels" hypothesis is in line with the explanation above, according to which corruption brings a negative impact on economy, and it is supported by some empirical findings, namely, Mauro $(1995,1998)$, Tanzi (1998), Bowles (2000), Jain (2001), and Chang (2013). On the other hand, the "grease the wheels" hypothesis considers corruption as a lubricant that is able to support and improve economic performance, particularly,for the economy with ill-functioning institutions. Those having "direct access" to public authority agree with bribery in order to not deal with long bureaucratic demands, as strict rules and tiring procedures. By doing so, efficiency can be improved, thus, acceleration of economic growth can be achieved (Egger \& Winner, 2005; Sena \& Martianova, 2008; Gazda, 2010; Meon, 2010; Dreher \& Gassebner, 2011).

Corruption also brings effects to bilateral trade flows, as stated in (Bandyopadhyay and Roy, 2016). There is a negative relation between export of particular goods by developed countries and their domestic corruption level; meanwhile, high level of corruption in a partner country's has negative impact on developed countries' particular goods export. Fluctuations in import activities of a country, on the other hand, seem to be less sensitive to changes in the perception of corruption. Furthermore, (Belloc, 2006) underlines the importance of studies on the effects of corruption on international trade, especially the ones related to asymmetric information, opportunist behavior, and export and import policy lobbying that can provoke those involved in corruption and finally influence the pattern of cross-country trade transactions.

The topic of the corruption impact on bilateral trade activities has also been revealed through the term of "mystery of missing trade" introduced by (Trefler, 1995). His point is that the volume of international trade that occurs is actually much smaller than what is assumed by economic theory since there is also corruption involved. Ranjan and Lee (2007) also support the idea by considering that international trade volume will be bigger five times if there is no friction of interests. Other researchers investigating the role of corruption on bilateral trade activities are Anderson and Morcuouiller (2002), Gatti (2004), De Groot et al. (2004), Berkowitz et al. (2006), Nunn (2007), Levchenko (2007), Mohlaman et al. (2010), Mejeed (204), Marjit et al. (2014), Nunn and Trefler (2014), and Bandyopadhyay and Roy (2016).

This study mainly focuses on the effects of corruption perception on bilateral trade flows, on either export activities, or import by using the extension of the gravity model. Countries are classified into two cohorts, i.e. developed and developing countries. Moreover, there are some control variables considered in the model, such as national income, distance, foreign direct investment, and competitiveness.

The paper is structured as follows: Section two reviews the literature and explores some previous empirical papers. Section three describes the dataset and the empirical model specification. Section four presents the empirical results. Section five summarizes the main findings of the analysis. 


\section{REVIEW OF RELATED LITERATURE}

\subsection{Definition of corruption and economics of corruption}

To specify the meaning of corruption in cross-country study, it commonly follows the definition proposed by Transparency International (TI) and World Bank (WB) that states corruption as the abuse of public authority for private gain (Rose-Ackerman, 1999; World Bank, 2007). Based on the view of institutional economics, the activity of corruption will increase transaction costs, cause misallocation of public funds, stimulate inefficiencies and therefore it will inhibit productive economic activities (Ehrlich \& Lui, 1999; Svensson, 2005; Lambsdorff, 2007; Aidt, 2009). In addition, Anokhin and Schulze (2009) mention that corruption encourages distrust and uncertainty in government institutions and economic condition. Distrust and uncertainty are products of corruptive behavior triggered by several factors, including bureaucratic behavior irregularities in prevailing legal norms, weak role of anti-corruption institutions and law enforcement processes, strong culture of giving bribes, and inadequate principles of transparency in economic activities (Luo, 2004). Private gain obtained by bribee from briber is in the form not only money but also valuable assets as well as promotion of status, position, or career. Furthermore, promising to help or serving benefits in the future for bribee's families and companions can be considered also as private gain (Lambsdorff, 2007).

According to Andvig et al. (2000), corruption in the model of principal-agent-client is defined as the exchange of benefit and gain between two actors, which are agent and client. The agent is an actor trusted by the principal to run an authority. Positioning lower than the principal, the agent gains the authority for a task. Thus, the agent must obey rules decided by the principal in finishing the task that is agreed by both the agent and the principal. The principal's rules are applied by the agent to treat his client, and this activity is called rule-bound behavior. When the agent breaks the rules to acquire private gain by asking the client to do bribery, it means that the agent does corruption.

Amundsen (1999) categorizes corruption in public sector into several types, namely bribery, extortion, embezzlement, and fraud. In the case of bribery, the client will act as a briber and make a number of payments to the agent who is positioned as bribee for a number of benefits in certain services. Meanwhile, extortion is a condition when the agent utilizes his authority to get gain from the client by asking the client to pay the agent's service which is not supposed to be paid. This activity is mostly done with insistence, violence, and threat. Next, in the case of embezzlement, agents or parties trusted to manage public resources commit theft on resources that should be managed on behalf of the public and fraud happens when a public officer distorts information as well as manipulates facts and skills in order to get private gain. Fraud can be considered as an economic crime involving trickery or deceit.

Since Rose-Ackerman published "The Economics of Corruption" in 1975, studies regarding economics of corruption have attracted many economists. It has been noted that there are 3000 titles of articles investigating corruption afterward, and more than 500 articles specifically discuss corruption in the perspective of economics (Mishra, 2005). Ideas regarding the study of economics of corruption are mostly classified into three main factors of corruption: (1) economic factors; (2) political factors; and (3) social and cultural factors (Sandholtz \& Koetzle, 2000; Nwabuzor, 2005; Akcay, 2006; Pellegrini \& Gerlagh, 2008; Billger \& Goel, 2009; Ata \& Arvas, 2011; Agbiboa, 2011; Aggrey, 2012; Elbahnasawy \& Revier, 2012; Dong \& Torgler, 2013; Pieroni \& d'Agostino, 2013). In addition, the study of economics of corruption in its development can be traced from some studies finding out the effects of corruption toward economy activities, such as (1) the effects of corruption to real GDP (Mauro, 1996; Leite \& Weidman, 1999; Tanzi \& Davoodi, 2000; Abed \& Davoodi, 2000); (2) the effects of corruption to international trade (Anderson \& Marcouiller, 2002; De Groot et al., 2004; Wei, 2000a); (3) the effects of 
corruption to government expenditure (Mauro, 1998); (4) the effects of corruption to government revenue (Tanzi \& Davoodi, 2000); (5) the effects of corruption to the interest of investment (Henisz, 2000; Wei, 2000; Wei \& Javorcik, 2002); (6) the effects of corruption to the distribution of income and poverty (Husted, 1999); and (7) the effects of corruption to inflation (Al-Mahrubi, 2000).

\subsection{Corruption and bilateral trade flows}

Anderson and Marcouiller (2002) conduct a study using poor institutional quality (represented by the level of corruption and the imperfection of contract enforcement) as the indicator of trade transaction cost. Applying the approach of gravity model, a finding reveals that unqualified institutions hinder bilateral trade flows. Moreover, Ranjan and Lee (2007) try to investigate a particular aspect like institutional contract in the context of bilateral trade and find that contract enforcement (transparency) influences trade flow between two countries having different products but with homogenous characteristic.

De Groot et al. (2004) also conduct a study concerning the effects of governance and institutional quality toward bilateral trade. The finding of the study proves that governance and institutional quality gives impacts on bilateral trade. In line with that, Mohlmann et al. (2010) add about the possibility of the institutional regulations role, such as intangible trade barriers (e.g. bribery, grease money, or lobbies) in interfering the bilateral trade activities. A study done by Francois and Manchin (2013), meanwhile, finds out that the level of corruption influences the quality of infrastructure supporting bilateral trade activities. The quality of infrastructure in this case represents the institutional quality of a country. When a country relatively has low level of corruption, it has sufficient quality of infrastructure so that any process related to administration, regulation, and trade will be conducted efficiently and effectively. A country with insufficient infrastructure, on the other hand, tends to serve poor quality of service that leads to corruption.

Utilizing a framework of Heckscher-Ohlin-Samuelson-Vanek (HOSV), Marjit et al. (2014), moreover, investigate the relation between corruption and international trade pattern. By utilizing dynamic panel model and considering some variables, such as trade openness, corruption, and capital-labor ratio, the study finds that the contribution of international trade activity to national income in low-income countries (developing countries and relatively labor-abundant) is smaller compared to high-income countries (developed countries and relatively capital-abundant). Related to this, the study considers corruption to be the main contributor to the condition. Corruption is responsible for the deterioration of comparative advantage in developing countries that rely heavily on labor-intensive activities. Corruption is illustrated to have different implications for country's trade, where these implications will depend largely on the abundance of resource endowment in each country (labor-abundant or capital-abundant).

\section{EMPIRICAL STRATEGY}

\subsection{Data source}

Considering the characteristic (per capita income) of the samples' countries and adjusting for the availability of corruption data, Table 1 presents 30 countries as the final samples used by the study. Developed countries with high per capita income (19 countries) and low corruption perception level (17 countries) dominate the samples. The remaining samples, meanwhile, are 11 countries with middle per capita income and 13 countries with high corruption perception level. Lower-middle income and uppermiddle income countries are categorized into developing countries (11 countries), and high income ones 
belong to developed countries (19 countries). Countries selected in the study are representatives of all regions of the world (Asia, Africa, America, Europe, and the Pacific).

The data period spans from 1995 to 2016, but empirical model also involved the variable of competitiveness that uses data from 2005 to 2016. The details of data sources and variables definition are presented in Table 2 .

Table 1

The Samples of Countries Based on the Classification of Country Characteristic

(Average of Per capita Income and Economic Development)

\begin{tabular}{|c|c|c|c|c|}
\hline \multicolumn{3}{|c|}{ Average of Per capita Income } & \multicolumn{2}{|c|}{ Economic Development } \\
\hline $\begin{array}{c}\text { Lower-Middle } \\
\text { Income }\end{array}$ & $\begin{array}{l}\text { Upper-Middle } \\
\text { Income }\end{array}$ & $\begin{array}{c}\text { High } \\
\text { Income }\end{array}$ & $\begin{array}{c}\text { Developing } \\
\text { Countries }\end{array}$ & $\begin{array}{l}\text { Developed } \\
\text { Countries }\end{array}$ \\
\hline $\begin{array}{l}\text { Indonesia, } \\
\text { Philippines, and } \\
\text { India (3) }\end{array}$ & $\begin{array}{l}\text { Malaysia, } \\
\text { Thailand, China, } \\
\text { Argentina, Brazil, } \\
\text { Mexico, Turkey, } \\
\text { and South Africa } \\
\text { (8) }\end{array}$ & $\begin{array}{l}\text { Singapore, } \\
\text { Australia, New } \\
\text { Zealand, Japan, } \\
\text { South Korea, } \\
\text { Canada, United } \\
\text { Kingdom, } \\
\text { Germany, } \\
\text { Netherlands, } \\
\text { France, Italia, } \\
\text { Belgium, Spain, } \\
\text { Swiss, Denmark, } \\
\text { Finland, Portugal, } \\
\text { Norway, and USA } \\
\text { (19) }\end{array}$ & $\begin{array}{l}\text { Indonesia, } \\
\text { Malaysia, } \\
\text { Thailand, } \\
\text { Philippines, } \\
\text { China, India, } \\
\text { Argentina, Brazil, } \\
\text { Mexico, Turkey, } \\
\text { and South Africa } \\
\text { (11) }\end{array}$ & $\begin{array}{l}\text { Singapore, Australia, New } \\
\text { Zealand, Japan, Canada, } \\
\text { United Kingdom, South } \\
\text { Korea, Germany, } \\
\text { Netherlands, France, Italia, } \\
\text { Belgium, Spain, Swiss, } \\
\text { Denmark, Finland, Portugal, } \\
\text { Norway, and USA (19) }\end{array}$ \\
\hline
\end{tabular}

Source: World Bank, 2017

Notes: Lower-Middle Income (US\$1,006-US\$3,955); Upper-Middle Income (US\$3,956-US\$12,235); High-Income $(>=\mathrm{US} \$ 12,236)$.

\subsection{Empirical Model}

Adopting Bandyopadhyay and Roy (2016) by considering specification of baseline log-linear gravity, estimation in this study is done to the total of export value by country $i$ (reporter) to country $j$ (partner) in year $t\left(X_{j i t}\right)$ as well as the total of import value by country $i$ to country $j$ in year t $\left(M_{i j t}\right)$ from 1995 to 2016. On the other hand, empirical models involving competitiveness variables will use data from 2005 to 2016. The empirical model is generally grouped into four models, which are Model A, B, C, and D explained below.

\section{Model A}

$$
\begin{aligned}
\ln X_{i j t}=\beta_{1} \ln Y_{i t}+\beta_{2} \ln Y_{j t}+\beta_{3}\left(\ln Y_{i t}-\ln Y_{j t}\right)+\alpha_{1} \ln y_{i t}+\alpha_{2} \ln y_{j t} \\
+\alpha_{3}\left(\ln y_{i t}-\ln y_{j t}\right)+\mu_{1} C P I_{i t}+\mu_{2} C P I_{j t}+\mu_{12} C P I_{i t} * \text { DummyDev }_{i t} \\
+\mu_{21} C P I_{j t} * \text { DummyDev }_{i t}+\beta_{4} F D I_{i t}+\beta_{5} \text { lndistance }_{i j}+e_{i j t}
\end{aligned}
$$

where:

$$
\frac{\partial \ln X_{i j t}}{\partial C P I_{i t}}=\mu_{1}+\mu_{12} \text { DummyDev }_{i t}
$$




$$
\frac{\partial \ln X_{i j t}}{\partial C P I_{j t}}=\mu_{2}+\mu_{21} \text { DummyDevit }
$$

Model A presents the model of export activities $\left(X_{i j t}\right)$ conducted by the reporting country $(i)$ to the partner country ()). This study will investigate the effect of corruption $(C P I)$ in two kinds, namely individual and interaction. The individual effect of corruption on bilateral exports will be represented by $C P I_{i t}$ and $C P I_{j t}$, while the interaction effect in the corruption context will be indicated by the interaction between the corruption variables of the reporting country and partner country $\left(C P I_{i t}\right.$ and $\left.C P I_{j t}\right)$ with the reporting country's dummy variable (DummyDevit). DummyDevit will be 1 (one) if the reporting country belongs to developed country and be 0 (zero) if it is a developing country. CPI is the corruption perception level of a country represented by the corruption perception index (1 to 10). If the value of CPI of a country is big or close to 10 , it shows that corruption is rarely found in the country.

In Model $\mathrm{A}$, the relation between the corruption variable $(C P I)$ and the classification of the reporting country (DummyDevit) is reflected by $\left(\mu_{12} C P I_{i t}{ }^{*} D_{u m m y} \operatorname{Dev} v_{i t}\right)$ and $\left(\mu_{21} C P I_{j t}{ }^{*} \operatorname{Dummy} \operatorname{Dev}_{i t}\right)$. Equation (1a) describes that when the reporting country classified into developing country (Dummy $\operatorname{lev}_{i t}=0$ ), $\mu_{1}$ will be dominating thus the effects of domestic corruption $\left(C P I_{i t}\right)$ to bilateral export $\left(X_{i j t}\right)$ will be determined by coefficient $\mu_{1}$. For the reporting country belonging to developed country (DummyDevit $=1$ ), on the contrary, the effects of domestic corruption to its bilateral export tend to be bigger described by coefficient $\mu_{12}$ and $\mu_{1}$. With the same indication, the effects of the corruption of the partner country $\left(C P I_{j t}\right)$ to bilateral export $\left(X_{i j t}\right)$ can be presented in Equation (1b).

Other variables involved in Model A are Y (real income -GDP-) with constant value 2010, y (per capita real income) with constant value 2010, FDI, and distance. Differences between per capita real income of country $i$ and which of country $j\left(\ln y_{i t}-\operatorname{lny}_{j t}\right)$, meanwhile, is used to describe difference between the factor endowments of country $i$ and which of country $j$ as well as to be a proxy to show wage differences between country $i$ and country $j$. Meanwhile, differences on real income-GDP- between country $i$ and country $j\left(\ln Y_{i t} \ln Y_{j t}\right)$ is used to describe differences on market size between country $i$ and country $j$.

Next, Model B is similar to Model A, but it is different only in the context of dependent variable (bilateral import $-M_{i j t}$ ). Model $\mathrm{B}$ has orientation to investigate the effects of corruption and other considered control variables toward import activities. It is shown by Equation (2) as follows.

\section{Model B}

$$
\begin{gathered}
\ln M_{i j t}=\beta_{1} \ln Y_{i t}+\beta_{2} \ln Y_{j t}+\beta_{3}\left(\ln Y_{i t}-\ln Y_{j t}\right)+\alpha_{1} \ln y_{i t}+\alpha_{2} \ln y_{j t} \\
+\alpha_{3}\left(\ln y_{i t}-\ln y_{j t}\right)+\mu_{1} C P I_{i t}+\mu_{2} C P I_{j t}+\mu_{12} C P I_{i t} * \text { DummyDev }_{i t} \\
+\mu_{21} C P I_{j t} * \text { DummyDev }_{i t}+\beta_{4} F D I_{i t}+\beta_{5} \text { lndistance }_{i j}+e_{i j t}
\end{gathered}
$$

\section{Model C}

$$
\begin{aligned}
\ln X_{i j t}=\beta_{1} \ln & Y_{i t}+\beta_{2} \ln Y_{j t}+\beta_{3}\left(\ln Y_{i t}-\ln Y_{j t}\right)+\alpha_{1} \ln y_{i t}+\alpha_{2} \ln y_{j t} \\
& +\alpha_{3}\left(\ln y_{i t}-\ln y_{j t}\right)+\mu_{1} C I_{i t}+\mu_{2} C I_{j t}+\mu_{12} C I_{i t} * \text { DummyDev }_{i t} \\
& +\mu_{21} C \operatorname{CPI}_{j t} * \operatorname{DummyDev}_{i t}+\beta_{4} F D I_{i t}+\beta_{5} \text { lndistance }_{i j} \\
& +\beta_{6} \operatorname{Com}_{i t}+\beta_{7} \operatorname{Com}_{j t}+\beta_{8}\left(\text { Com }_{i t}-\text { Com }_{j t}\right)+e_{i j t}
\end{aligned}
$$

To be successful in getting maximum benefits from trade activities, a country should be optimal in utilizing its competitiveness (Goedhuys et al., 2016). A country with higher competitiveness is considered to be better to compete in international markets and increase its gain from trade. In order to reveal it, this 
study establishes Model C and Model D that consider the variable of competitiveness together with corruption to influence export and import activities.

\section{Model D}

$$
\begin{aligned}
& \ln M_{i j t}=\beta_{1} \ln Y_{i t}+\beta_{2} \ln Y_{j t}+\beta_{3}\left(\ln Y_{i t}-\ln Y_{j t}\right)+\alpha_{1} \ln y_{i t}+\alpha_{2} \ln y_{j t} \\
& +\alpha_{3}\left(\ln y_{i t}-\ln y_{j t}\right)+\mu_{1} C P I_{i t}+\mu_{2} C P I_{j t}+\mu_{12} C P I_{i t} * D_{u m m y D e v} \\
& +\mu_{21} C P I_{j t} * \text { DummyDev }_{i t}+\beta_{4} F D I_{i t}+\beta_{5} \text { lndistance }_{i j} \\
& +\beta_{6} \operatorname{Com}_{i t}+\beta_{7} \operatorname{Com}_{j t}+\beta_{8}\left(\operatorname{Com}_{i t}-\operatorname{Com}_{j t}\right)+e_{i j t}
\end{aligned}
$$

\begin{tabular}{|c|c|c|c|}
\hline Variable & Definition & Unit & Source \\
\hline $\begin{array}{l}\text { Export } \\
(\mathrm{X})\end{array}$ & Total value of export & Million US\$ & UN Comtrade \\
\hline $\begin{array}{l}\text { Import } \\
(\mathrm{M})\end{array}$ & Total value of import & Million US\$ & UN Comtrade \\
\hline $\begin{array}{l}\text { Corruption } \\
(\mathrm{CPI})\end{array}$ & $\begin{array}{l}\text { Corruption level measured by corruption } \\
\text { perception index }\end{array}$ & $\begin{array}{l}\text { Corruption Perception Index } \\
\text { (CPI) }\end{array}$ & $\begin{array}{l}\text { Transparency } \\
\text { International }\end{array}$ \\
\hline $\begin{array}{l}\text { Per capita Real } \\
\text { Income } \\
\text { (y) }\end{array}$ & Per capita real GDP in a country & Thousand US\$ & World Bank \\
\hline $\begin{array}{l}\text { Real Income } \\
(\mathrm{Y})\end{array}$ & $\begin{array}{l}\text { Total of real GDP obtained by a country in } \\
\text { a year }\end{array}$ & Billion US\$ & World Bank \\
\hline Distance & $\begin{array}{l}\text { Distance between countries } \\
\text { (measured from each capital city) }\end{array}$ & Kilometer $(\mathrm{km})$ & Google Map \\
\hline FDI & $\begin{array}{l}\text { The value of FDI obtained is compared } \\
\text { with GDP }\end{array}$ & $\%$ of GDP & World Bank \\
\hline $\begin{array}{l}\text { Competitiveness } \\
(\mathrm{Com})\end{array}$ & $\begin{array}{l}\text { Competitiveness of a country with index } \\
\text { unit }\end{array}$ & Competitiveness Index & $\begin{array}{l}\text { World Economic } \\
\text { Forum }\end{array}$ \\
\hline DummyDev & $\begin{array}{l}\text { Dummy describing country classification } \\
\text { (developed or developing countries) }\end{array}$ & $\begin{array}{l}1=\text { developed country } \\
0=\text { developing country }\end{array}$ & World Bank \\
\hline
\end{tabular}

Table 2

Variables Definition and Data Source

\section{EMPIRICAL RESULTS AND DISCUSSION}

Table 3 and Table 4 below explain the relation between variables considered in the study by referring to the execution of equations in Model A, B, C, and D. The result reveals that Random Effect Model is the best panel model that can be applied to Model A and B. Model A and B are created in order to identify the asymmetric impact of corruption on bilateral exports and imports of developed and developing countries. However, it must be noted that corruption in Random panel model is considered as a component of trade costs like distance that has been broadly known as a proxy of the component of trade costs in the gravity model for bilateral trades.

Either Model A or Model B (presented in Table 3) and both Model C and Model D (presented in Table 5) basically are reduced form equations describing two points, i.e. the condition of IRS (Increasing Return to Scale) in monopolistic competitive markets and a condition explained in factor proportions theory of trade. Export activities are expected to be related to the market size of the partner country in which the market size is reflected by the variable of real income-GDP- (Y). The factor of relative endowments measured by per capita income $(y)$ is considered to be a factor to determine trade flows as well. 
The Result of Regression of Model A and Model B

\begin{tabular}{|c|c|c|}
\hline $\begin{array}{l}\text { Model } \\
\text { Variables }\end{array}$ & Model A & Model B \\
\hline $\operatorname{LnY} Y_{i t}$ & $\begin{array}{l}0.903^{* * *} \\
(0.023)\end{array}$ & $\begin{array}{l}0.991^{* * *} \\
(0.021)\end{array}$ \\
\hline $\operatorname{LnY}_{\mathrm{jt}}$ & $\begin{array}{l}1.056^{* * *} \\
(0.020)\end{array}$ & $\begin{array}{l}0.893^{* * *} \\
(0.006)\end{array}$ \\
\hline $\operatorname{Ln}\left(Y_{i t^{-}} Y_{j t}\right)$ & $\begin{array}{l}0.047^{* * *} \\
(0.007)\end{array}$ & $\begin{array}{l}0.061^{* * *} \\
(0.007)\end{array}$ \\
\hline Lny $_{\text {it }}$ & $\begin{array}{l}0.261^{* * *} \\
(0.029) \\
\end{array}$ & $\begin{array}{l}0.348^{* * *} \\
(0.027) \\
\end{array}$ \\
\hline $\operatorname{Lny}_{j t}$ & $\begin{array}{l}0.256^{* * *} \\
(0.025)\end{array}$ & $\begin{array}{l}0.152^{* * *} \\
(0.024)\end{array}$ \\
\hline $\operatorname{Ln}\left(y_{i t}-y_{j t}\right)$ & $\begin{array}{l}-0.008 \\
(0.007)\end{array}$ & $\begin{array}{c}0.002 \\
(0.007)\end{array}$ \\
\hline$C P I_{i t}$ & $\begin{array}{c}0.005 \\
(0.009)\end{array}$ & $\begin{array}{l}0.073^{* * *} \\
(0.008)\end{array}$ \\
\hline $\mathrm{CPI}_{\mathrm{jt}}$ & $\begin{array}{l}0.046^{* * *} \\
(0.009)\end{array}$ & $\begin{array}{l}0.025^{* * *} \\
(0.008)\end{array}$ \\
\hline$C P I_{i t}{ }^{*} D u m m y D e v_{i t}$ & $\begin{array}{l}-0.009 \\
(0.010) \\
\end{array}$ & $\begin{array}{c}-0.058^{* * *} \\
(0.010)\end{array}$ \\
\hline $\mathrm{CPI}_{\mathrm{jt}}{ }^{*} \mathrm{DummyDev}_{\mathrm{it}}$ & $\begin{array}{c}-0.043^{* * *} \\
(0.010)\end{array}$ & $\begin{array}{c}-0.059^{* * *} \\
(0.009)\end{array}$ \\
\hline LnDistance & $\begin{array}{c}-0.867^{* * *} \\
(0.036)\end{array}$ & $\begin{array}{c}-0.811^{* * *} \\
(0.033)\end{array}$ \\
\hline FDI & $\begin{array}{l}0.003^{* * *} \\
(0.001)\end{array}$ & $\begin{array}{l}0.004^{* * *} \\
(0.001)\end{array}$ \\
\hline $\mathrm{N}$ & 19140 & 19140 \\
\hline Adjusted $\mathrm{R}^{2}$ & 0.6560 & 0.6628 \\
\hline
\end{tabular}

Notes: 1. ${ }^{* * *}=$ significant in $1 \%$; $* *=$ significant in $5 \%$; $*$ significant in $10 \%$

2. Dependent Variables: LnX $X_{i j t}$-Export- (Model A); LnMijt-Import- (Model B).

This paper introduces the natural logarithm of absolute difference in the GDP of country $i$ and $j$ $\left(\ln Y_{i t}-\ln Y_{j t}\right)$ to describe substitution pattern from bilateral trade to FDI activities. It follows the argument of Markusen \& Venables (2000) who verify the major share of intra-industry trade among MNCs from developed countries in forming manufacturing trade. So, when positive trade costs condition is exist and countries found to be more identical in factor endowments, then the establishment of MNCs (through horizontal FDI) will tend to be opted for substituting bilateral trade activities. The natural logarithm from value differences of real per capita income between country $i$ and country $j$ (lnyit-lny $y_{j}$ ) is used as a variable determining bilateral trade, particularly to present differences on the factor of endowment between country $i$ and country $j$ (also as a proxy to show wage differences between country $i$ and country $j$ ).

In Table 3, Model A describes how market size-GDP $(Y)$ of the partner country significantly influences bilateral exports. Since the coefficient of GDP of the partner country is found bigger than the reporting country, this study verifies the reversed home market effect, i.e. export elasticity tends to be more dominantly described by the income or market size of the partner country than by domestic income (Krugman, 1980). Corroborating the idea of Markusen and Venables (2000), this paper finds positive and significant effect of relative country size on bilateral export so that it fails in demonstrating a substitution pattern of bilateral export and FDI. Since the variable of $\left(l_{n y} y_{i-l} \ln _{j}\right)$ describing differences in the factor of 
endowment between country $i$ and country $j$ has no significant effect on bilateral export activities, it indicates that the framework of the theory of Heckser-Ohlin (HO) is not verified in this study.

The results for distance and FDI (Foreign Direct Investment) have confirmed other previous studies. While distance gives a negative effect to bilateral export, FDI shows a positive significant impact to export. Domestic corruption, moreover, does not have any significant effects to bilateral exports, either in developed countries or developing countries. However, the asymmetric effects from the corruption level of the partner country significantly appear in the case of exports. When the relation between $C P I_{j t}$ and $X_{j i t}$ is positive, it indicates that the reporting country will do more export activities to the partner country if the partner country is far from corruption tendency. The positive effects of low corruption level in the partner country to bilateral export are found to be more apparent in developing countries than in developed countries.

The characteristics of bilateral import in Model B tend to be similar to bilateral exports in Model A, for instance the income elasticity of import of the exporting country $(\lambda)$ is found to be smaller than the one of the importing country ( $(2$. Real per capita income has positive and significant effect on bilateral imports in which high income in the importing country will be associated with more import activities done by the country. That fact, according to Markusen (2013), can be utilized to be an indication of preference of nonidentical and non-homothetic in import activities.

Table 4

The Individual and Interaction Effect of Corruption Variable in Model A and B

\begin{tabular}{|c|c|c|}
\hline Individual & Interaction & Relationship \\
\hline \multicolumn{3}{|l|}{ Model $A$} \\
\hline$C P I_{i t}$ & & $C P I_{i t} \nrightarrow X_{i j t}$ \\
\hline \multirow[t]{3}{*}{$\mathrm{CPI}_{\mathrm{jt}}$} & & $\mathrm{CPI}_{\mathrm{jt}} \longrightarrow X_{i j t}(+)$ \\
\hline & $C P I_{i t}{ }^{*} D_{u m m y D e v_{i t}}=1$ & $\mathrm{CPI}_{\mathrm{it}} \nrightarrow X_{i j t}$ \\
\hline & $\mathrm{CPI}_{\mathrm{jt}}{ }^{*} \mathrm{Dummy} \mathrm{vv}_{i t}=1$ & $\mathrm{CPI}_{\mathrm{jt}}(\mathrm{i}=0)>\mathrm{CPI}_{\mathrm{jt}}(\mathrm{i}=1)$ \\
\hline \multicolumn{3}{|l|}{ Model B } \\
\hline$C P I_{i t}$ & & $C P I_{i t} \longrightarrow X_{i j t}(+)$ \\
\hline \multirow[t]{3}{*}{$\mathrm{CPI}_{\mathrm{jt}}$} & & $\mathrm{CPI}_{j t} \longrightarrow X_{i j t}(+)$ \\
\hline & $C P I_{i t}{ }^{*} D_{u m m y D e v_{i t}}=1$ & $\mathrm{CPI}_{\mathrm{it}}(\mathrm{i}=0)>\mathrm{CPI}_{\mathrm{it}}(\mathrm{i}=1)$ \\
\hline & $\mathrm{CPI}_{\mathrm{jt}}{ }^{*}$ DummyDevit $=1$ & $\mathrm{CPI}_{\mathrm{jt}}(\mathrm{i}=0)>\mathrm{CPI}_{\mathrm{jt}}(\mathrm{i}=1)$ \\
\hline
\end{tabular}

Notes: $1 .(+)=$ positive effect; $i=0$ means the reporting country is developing country; $i=1$ means the reporting country is developed country

However, it is found that a low domestic corruption level will positively affect the reporting countries' import activities and the fact becomes more apparent for the developing countries (see Table 4). The low level of domestic corruption will improve the performance of import activities, as well as the low level of partner countries' corruption will significantly increase imports. Improving the severity of corruption in partner countries will encourage all bilateral trade activities in a better direction. Compared to export activities, import activities look more sensitive to corrupt behavior. From the significant negative coefficient of the interaction variable $\left(C P I_{j t}^{*}\right.$ Dummy Dev $\left._{i t}\right)$ in both Model -A and B-, it is obtained that the influence of partner countries' level of corruption will be greater if the reporting countries classified as a developing country. 
The Result of Regression of Model C and Model D

\begin{tabular}{|c|c|c|}
\hline Variables & Model C & Model D \\
\hline $\operatorname{LnY}_{\text {it }}$ & $\begin{array}{c}0.750^{* * *} \\
(0.011)\end{array}$ & $\begin{array}{c}0.805^{* * *} \\
(0.010)\end{array}$ \\
\hline $\operatorname{LnY}_{j t}$ & $\begin{array}{c}0.739^{* * *} \\
(0.010)\end{array}$ & $\begin{array}{c}0.739^{* * *} \\
(0.010)\end{array}$ \\
\hline $\operatorname{Ln}\left(Y_{\mathrm{it}^{-}} \mathrm{Y}_{\mathrm{it}}\right)$ & $\begin{array}{c}0.056^{* * *} \\
(0.009)\end{array}$ & $\begin{array}{c}0.060^{* * *} \\
(0.007)\end{array}$ \\
\hline Lny $_{\text {it }}$ & $\begin{array}{c}-0.099^{* * *} \\
(0.019)\end{array}$ & $\begin{array}{c}-0.187^{* * *} \\
(0.018)\end{array}$ \\
\hline Lny $_{j t}$ & $\begin{array}{c}-0.183^{* * *} \\
(0.013)\end{array}$ & $\begin{array}{c}-0.289^{* * *} \\
(0.012)\end{array}$ \\
\hline $\operatorname{Ln}\left(y_{i t}-y_{j t}\right)$ & $\begin{array}{c}-0.098^{* * *} \\
(0.009)\end{array}$ & $\begin{array}{c}-0.078^{* * *} \\
(0.008)\end{array}$ \\
\hline$C P I_{i t}$ & $\begin{array}{l}0.114^{* * *} \\
(0.021)\end{array}$ & $\begin{array}{c}0.193^{* * *} \\
(0.019)\end{array}$ \\
\hline $\mathrm{CPI}_{\mathrm{jt}}$ & $\begin{array}{l}0.0003 \\
(0.006)\end{array}$ & $\begin{array}{c}-0.019^{* * *} \\
(0.005)\end{array}$ \\
\hline$C P I_{i t}{ }^{*} D u m m y D e v_{i t}$ & $\begin{array}{c}-0.137^{* * *} \\
(0.010)\end{array}$ & $\begin{array}{c}-0.121^{* * *} \\
(0.010)\end{array}$ \\
\hline $\mathrm{CPI}_{\mathrm{jt}} * \mathrm{DummyDev}_{\mathrm{it}}$ & $\begin{array}{c}0.011 \\
(0.007)\end{array}$ & $\begin{array}{l}0.018^{* *} \\
(0.007)\end{array}$ \\
\hline $\operatorname{Com}_{\text {it }}$ & $\begin{array}{c}0.697^{* * *} \\
(0.033)\end{array}$ & $\begin{array}{c}0.299^{* * *} \\
(0.031)\end{array}$ \\
\hline $\mathrm{Com}_{\mathrm{jt}}$ & $\begin{array}{c}0.420^{* * *} \\
(0.024)\end{array}$ & $\begin{array}{c}0.558^{* * *} \\
(0.023)\end{array}$ \\
\hline$\left(\mathrm{Com}_{\mathrm{it}}{ }^{-} \mathrm{Com}_{\mathrm{jt}}\right)$ & $\begin{array}{l}-0.010 \\
(0.022)\end{array}$ & $\begin{array}{c}-0.061^{* * *} \\
(0.021)\end{array}$ \\
\hline LnDistance & $\begin{array}{c}-0.921^{* * *} \\
(0.011)\end{array}$ & $\begin{array}{c}-0.849^{* * *} \\
(0.010)\end{array}$ \\
\hline FDI & $\begin{array}{l}0.020^{* * *} \\
(0.001)\end{array}$ & $\begin{array}{c}0.023^{* * *} \\
(0.001)\end{array}$ \\
\hline $\mathrm{N}$ & 10440 & 10440 \\
\hline Adjusted $\mathrm{R}^{2}$ & 0.7386 & 0.7550 \\
\hline
\end{tabular}

Notes: 1. $* * *=$ significant in $1 \% ; * *=$ significant in $5 \%$; $*$ = significant in $10 \%$

2. Dependent Variables: $L n X_{i j t}$-Export- (Model C); $L n M_{i j t}$-Import- (Model D)

Next, Table 5 presents Model C and Model D considering the influence of competitiveness of the reporting country (i) and the partner country $(j)$ to both bilateral exports and imports. This study finds Common Effect Model as the best panel model that can be used for Model C and D. After considering the influence of reporting and partner country's competitiveness in the model (Comit and $C_{0 m}{ }_{j i}$ ), this paper finds more significant independent variables on the regression results.

The low domestic corruption level appears to have a positive significant effect to the improvement of bilateral trade activities (export and import). The low severity of corruption at the domestic level is related to the high intensity of exports $\left(X_{i j t}\right)$ and imports $\left(M_{i j t}\right)$ among reporting countries and their partners. On other side, the influence of the partner countries' corruption level $\left(C P I_{j t}\right)$ is seen to be only significant for import activities. The positive effects of low corruption level in the reporting country to bilateral import are found to be more apparent in developing countries than in developed countries. 
The market size-GDP $(Y)$ of the reporting $\left(Y_{i t}\right)$ and partner country $\left(Y_{j t}\right)$ significantly influences bilateral exports. Since the coefficient of GDP of the reporting country is found bigger than the partner country, this study verifies the home market effect. This study also finds evidence that differences in market size $\left(\ln Y_{i r} \ln Y_{j t}\right)$ and factor endowments $\left(\ln y_{i-} \ln y_{j i t}\right)$ have significant effect on export and import activities. The influence of distance (Indistance) is also verified negatively on Models $\mathrm{C}$ and $\mathrm{D}$, indicating that export and import activities still consider the adverse effect of transportation costs. In addition, FDI is still found to have a positive contribution to both bilateral trade activities (exports and imports).

Both models specifically show the significant positive impact of competitiveness (Comit and $\left.C_{0} m_{j}\right)$ on import and export activities. This finding supports the opinion that exports will be carried out by countries that have relatively higher competitiveness compared to partner countries (importers) and import activities will be carried out by a country if the competitiveness of partner countries is higher than domestic competitiveness. Competitiveness differences between reporting and partner country (Comit$C m_{j t}$ ) are found to be negatively affect their import activities (see Model D). The higher competitiveness differences between countries appeared in import activities, the less bilateral import activities done by the two countries. However, competitiveness differences between reporting and partner country $\left(\right.$ Com $_{i-}$ Com $\left._{j}\right)$ do not influence their export activities (see Model C).

\section{CONCLUSION}

This paper uses an extension of gravity panel model in investigating the impact of corruption and other considered control variables on bilateral trade (exports and imports) among developed and developing countries. There are four models which are executed, namely Model A, B, C, and D. Model A reveals that domestic corruption is found to have no significant effect on bilateral exports in both developed countries and developing countries. The asymmetric effects of the partner country's corruption level significantly appear in reporting country export activities. A positive relation between $C P I_{j t}$ and $X_{j i t}$ indicates that the reporting country ( $($ ) will have more export activities conducted with the partner country (j) if the partner country has low tendency in doing corruption. That positive effect of the low corruption level of the partner country to reporting country's bilateral export activities is found higher in the developing countries than in the developed ones. Meanwhile, bilateral exports are also significantly influenced by market size-GDP ( $Y_{i t}$ and $Y_{j i}$ ). Since a positive and significant relation between relative country size and bilateral exports occurs, it can be concluded that there is no substitution patterns between bilateral exports and FDI. Next, differences in factor endowments between country $i$ and country $j\left(\ln _{i t}-\ln y_{j t}\right)$ are not significantly related to bilateral export activities, and this condition indicates the framework of Heckser-Ohlin (HO) fails to be verified.

In Model B, the income elasticity of import of the exporting country ( $)$ is smaller than which of the importing country $(i)$. The impact of domestic real per capita income $\left(y_{i t}\right)$ on bilateral imports $\left(M_{i j t}\right)$ is positive and significant in which the high income of the importing country will be associated with the high import conducted by the country. A fact reveals that the preference of non-identical and non-homothetic have a dominant role in explaining import activities. From Model C and D, the study verifies the home market effect and the negative effect of competitiveness differences between reporting and partner country $\left(\right.$ Comit $\left._{i-} \mathrm{Com}_{j t}\right)$ on import activities.

Further research is needed on expanding the period used in the study and considering the interaction effect of a specific institutional characteristic in each country related to the corruptive behaviour (such as an establishment a new official body or system). More methodological work is also needed on how to robustly figure out the short and long run relationship between bilateral trade and corruption perception. 


\section{REFERENCES}

Abed, G.T., \& Davoodi, H.R. (2000). Corruption, structural reforms, and economic performance in the transition economies. IMF Working Paper, No. 00/132, 1-41.

Agbiboa, D.E. (2011). Between corruption and development: the political economy of state Robbery in Nigeria. Journal of Business Ethics, 108(3), 325-345. doi: https://doi.org/ 10.1007/s10551-011-1093-5.

Aggrey, N. (2012). Determinants of corruption at district levels in Uganda. International Journal of Economic Perspectives, 6(4), 67-72.

Aidt, T.S. (2009). Corruption, institutions and economic development. Oxford Review of Economic Policy, 25, $271-91$. doi: https://doi.org/10.17863/CAM.5625.

Akcay, S. (2006). Corruption and human development. Cato Journal, 26(1), 29-48.

Al-Marhubi, F.A. (2000). Corruption and Inflation. Economics Letters, 66(2), 199-202. doi: https://doi.org/10.1016/S0165-1765(99)00230-X

Amundsen, I. (1999). Political corruption: An introduction to the issues. CMI Working Paper WP 1999(7). Retrieved from: https://www.cmi.no/publications/1040-political-corruption.

Anderson, C.J., \& Tverdova, Y.V. (2003). Corruption, political allegiances, and attitudes toward government in contemporary democracies. American Journal of Political Science, 47(1), 91-109. doi: https://doi.org/10.1111/1540-5907.00007.

Anderson J.E., \& Marcouiller D. (2002). Insecurity and the pattern of trade: An empirical investigation. The Review of Economics and Statistics, 84, 342-352. doi: https://doi.org/10.1162/003465302317411587.

Andvig, J.C., Fjeldstadt, O.H., Amundsen, I., Sissener, T., \& Soreide, T. (2000), Research on corruption: A Policy oriented survey. CMI \& NUPI Working Paper.

Anokhin, S., \& Schulze, W.S. (2009). Entrepreneurship, innovation, and corruption. Journal of Business Venturing, 24(5), 465-476. doi: https://doi.org/10.1016/j.jbusvent.2008.06.001.

Ata, A.Y., \& Arvas, M.A. (2011). Determinants of economic corruption: A cross-country data analysis. International Journal of Business and Social Science, 2(13), 161-169.

Bandyopadhyay, S., \& Roy, S. (2016). The effects of corruption on trade flows: A disagregated analysis. Retrieved http://www.researchgate.net/publication/303562996.

Bardhan, P. (1997). Corruption and development: A review of issues. Journal of Economic Literature, 35(3), 1320-1346.

Belloc, M. (2006). Institutions and international trade: A reconsideration of comparative advantage. J Econ Surveys, 20, 3-26. doi: https://doi.org/10.1111/j.0950-0804.2006.00274.x.

Berkowitz D., Moenius J., \& Pistor K. (2006). Trade, law, and product complexity. Rev Econ Stat, 88, 363-373. doi: https://doi.org/10.1162/rest.88.2.363.

Billger, S.M., \& Goel, R.K. (2009). Do existing corruption levels matter in controlling corruption?: Cross-country quantile regression estimates. Journal of Development Economics, 90(2), 299-305. doi: https://doi.org/10.1016/j.jdeveco.2008.07.006.

Bowles, R. (2000). Corruption. In B. Boudewijn and G. De Greest, eds. Encyclopedia of Law and Economics. The Economics of Crime and Litigation, 5, 460-491. Edward Elgar.

Chang, E.C.C. (2013). A comparative analysis of how corruption erodes institutional trust. Taiwan Journal of Democracy, 9(1), 73-92.

Chang, E.C., \& Chu, Y.H. (2006). Corruption and trust: Exceptionalism in Asian democracies?. Journal of Politics, 68(2), 259-271. doi: https://doi.org/10.1111/j.1468-2508.2006.00404.x.

De Groot, H.L.F., Linders G., Rietveld, P., \& Subramanian, U. (2004). The institutional determinants of bilateral trade patterns. Kyklos, 57(1), 103-123. doi: https://doi.org/10.1111/j.0023-5962.2004.00245.x.

Della Porta, D. (2000). Social capital, beliefs in government, and political corruption. In S.J. Pharr \& R.D. Putnam (Eds.), Disaffected democracies: What's troubling the trilateral countries? Princeton, Princeton University Press.

Dimakou, O. (2015). Bureaucratic corruption and the dynamic interaction between monetary and fiscal policy. European Journal of Political Economy, 40, 57-78. doi: https://doi.org/10.1016/j.ejpoleco.2015.07.004.

Dong, B., \& Torgler, B. (2012). Causes of corruption: Evidence from China. China Economic Review, 26(3), $152-169$. doi: https://doi.org/10.1016/j.chieco.2012.09.005. 
Dreher, A., \& Gassebner, M., (2011). Greasing the wheels ? The impact of regulations and corruption on firm entry. Journal of Public Choice, 155(3), 413-432. doi: https://doi.org/10.1007/s11127-011-9871-2.

Egger, P., \& Winner, H. (2005). Evidence on corruption as an incentive for foreign direct investment. European Journal of Political Economy, 21(4), 932-952. doi: https://doi.org/10.1016/j.ejpoleco.2005.01.002.

Elbahnasawy, N., \& Revier, C.F. (2012). The determinants of corruption: Cross-country-panel-data analysis. The Developing Economies, 50(4), November: 311-333. doi: https://doi.org/10.1111/j.1746-1049.2012.00177.x.

Ertimi, B.E., \& Saeh, M.A. (2013). The impact of corruption on some aspects of the economy. International Journal of Economics and Finance, 5(8), 1-8.

Feenstra, R.C., \& Taylor, A.M. (2014). International economics. New York, Worth Publisher.

Francois, J., \& Manchin, M. (2013). Institutions, infrastructure, and trade. World Dev, 46, 165-175. doi: https://doi.org/10.1596/1813-9450-4152.

Gatti, R. (2004). Explaining corruption: Are open countries less corrupt?. Journal of International Development, 16(6). doi: https://doi.org/10.1002/jid.1115.

Gazda, K. (2010). Does corruption "grease the wheels" of growth? Empirical evidence from MENA countries. Working Paper on Laboratoire d'Economie et de Finance Appliquée (LEFA) - IHEC Carthage.

Goedhuys, M., Mohnen, P., \& Taha, T. (2016). Corruption, innovation and firm growth: firm-level evidence from Egypt and Tunisia. Eurasian Bus Rev, 6, 299-322.

Henisz, W.J. (2000). The institutional environment for multinational investment. Journal of Law, Economics and Organization, 16(2), 334-364. doi: https://doi.org/10.1093/jleo/16.2.334.

Huang, C.J. (2016). Is corruption bad for economic growth? Evidence from Asia-Pacific countries. The North American Journal of Economics and Finance, 35, 247-256.

Husted, B.W. (1999). Wealth, culture, and corruption. Journal of International Business Studies, 30(2), 339-359. doi: https://doi.org/10.1057/palgrave.jibs.8490073.

Jain, A.K. (2001). Corruption: A review. Journal of Economic Surveys, 15(1), 71-121. doi: https://doi.org/10.1111/14676419.00133 .

Krugman, P.R. (1980). Scale economies, product differentiation, and the pattern of trade. American Economic Review, 70, 950-959.

Krugman, P.R., Obstfeld, M., \& Melitz, M.J. (2012). International economics: Theory and policy. Addison-Wesley.

Lambsdorff, J.G. (2007). The institutional economics of corruption and reform: Theory, evidence and policy. Cambridge University Press.

Leite, C. \& Weidmann, J. (1999). Does mother nature corrupt natural resources, corruption, and economic growth. IMF Working Paper, 99(85), 1-30. doi: http://dx.doi.org/10.2139/ssrn.259928.

Levchenko, A.A. (2007). Institutional quality and international trade. Rev Econ Stud, 74, 791-819. doi: https://doi.org/10.2139/ssrn.646183.

Luo, Y. (2004). An organisational perspective of corruption. Management and Organisation Review: 119-154. doi: https://doi.org/10.1111/j.1740-8784.2004.00006.x.

Majeed, M.T. (2014). Corruption and trade. Journal of Economic Integration, 29(4), 759-782. doi: https://doi.org/10.11130/jei.2014.29.4.759.

Marjit, M., Mandal, B., \& Roy, S. (2014). Trade openness, corruption and factor abundance: Evidence from a dynamic panel. Rev Dev Econ, 18: 45-58. doi: https://doi.org/10.1111/rode.12068.

Markusen, J.R. (2013). Putting per-capita income back into trade theory. Journal of International Economics, 90, 255-265. doi: https://doi.org/10.3386/w15903.

Markusen, J.R., \& Venables, A.J. (2000). The theory of endowment, intra-industry and multi-national trade. J Int Econ, 52, 209-234. doi: https://doi.org/10.1016/S0022-1996(99)00055-0.

Mauro, P. (1995). Corruption and growth. The Quarterly Journal of Economics, 110(3), 681-712. doi: https://doi.org/10.2307/2946696.

Mauro, P. (1996). The effects of corruption on growth, investment, and government expenditure. IMF Working Paper, No. 96/98, 1-28.

Mauro, P. (1998). Corruption: Causes, consequences, and agenda for further research. Finance \& Development, 35(1), 12-14. 
Menard, A.L. \& Weill, L. (2016). Understanding the link between aid and corruption: A causality analysis. Economic Systems, 40(2), 260-272. doi: https://doi.org/10.1016/j.ecosys.2016.01.001.

Meon, P.G. (2010). Is Corruption an efficient grease?. World Development, 38(3), 244-259. doi: https://doi.org/10.1016/j.worlddev.2009.06.004.

Mishra, A. (2005). The Economics of Corruption. Oxford University Press.

Mohlmann, L.J., Ederveen S., De Groot, H.L.F., \& Linders G. (2010). Intangible barriers to trade: a sectoral approach. In: van Bergeijk PAG, Brakman $S$ (eds) The gravity model in international trade: advances and applications. Cambridge University Press, Cambridge, pp 224-251.

Nunn, N. (2007). Relationship-specificity, incomplete contracts, and the pattern of trade. Quart J Econ, 122, 569-600. doi: https://doi.org/10.1162/qjec.122.2.569.

Nwabuzor, A. (2005). Corruption and development: New initiatives in economic openness and strengthened rule of law. Journal of Business Ethics, 59(1), 121-138. doi: https://doi.org/10.1007/s10551-005-3402-3.

Pellegrini, L. \& Gerlagh, R. (2008). Causes of Corruption: A Survey of cross-country analyses And Extended Results. Economics of Governance, 9(3), 245-263. Doi: https://doi.org/10.1007/s10101-007-0033-4.

Pieroni, L. \& d'Agostino, G. (2013). Corruption and the effects of economic freedom. European Journal of Political Economy, 29, 54-72. doi: https://doi.org/10.1016/j.ejpoleco.2012.08.002.

Pugel, T.A. (2016). International economics. New York, McGraw-Hill Education, New York.

Ranjan, P., \& Lee J.Y. (2007). Contract enforcement and international trade. Econ Politics, 19, 191-218. doi: https://doi.org/10.1111/j.1468-0343.2007.00308.x.

Rose-Ackerman, S. (1975). The economics of corruption. Journal of Political Economy, 4, 187-203. doi: https://doi.org/10.1016/0047-2727(75)90017-1.

Rose-Ackerman, S. (1999). Corruption and government: Causes, consequences, and reform. Cambridge University Press. doi: https://doi.org/10.1017/CBO9781139175098

Sandholtz, W., \& Koetzle, W. (2000). Accounting for corruption: Economic structure, democracy, and trade. International Studies Quarterly, 44(1), 31-50. doi: https:/ /doi.org/10.1111/0020-8833.00147.

Sena, V., \& Martianova, N. (2008). Corruption and foreign direct investment in Russian regions. Unpublished Working Paper. Aston Business School, United Kingdom.

Tanzi, V. (1998). Corruption around the world: Causes, consequences, scope, and cures. Staff Papers - International Monetary Fund, 45(4), 559-594. doi: https:/ / doi.org/10.2307/3867585.

Tanzi, V., \& Davoodi, H.R. (2000). Corruption, growth, and public finances. IMF Working Paper, No. 00/182, 1-27. Retrieved from: https://www.imf.org/en/Publications/WP/Issues/2016/12/30/Corruption-Growth-andPublic-Finances-3854.

Trefler, D. (1995). The case of the missing trade and other mysteries. Am Econ Rev, 85: 1029-1046.

Varvarigos, D., \& Arsenis, P. (2015). Corruption, fertility, and human capital. Journal of Economic Behavior \& Organization, 109, 145-162. doi: https://doi.org/10.1016/j.jebo.2014.11.006.

Wei, S.J. (2000). How taxing is corruption on international investors?. The Review of Economics and Statistics, 82(1), 1-11. doi: https://doi.org/10.1162/003465300558533.

Wei, S.J. (2000a). Natural openness and good government. NBER. Working Paper, 7765. Retrieved from http://www.nber.org/papers/w7765.

Wei S.J., \& Javorcik B.S. (2002). Corruption and cross-border investment: firm level evidence. William Davidson Institute Working Paper, 494, 1-29.

WorldBank (2007). Helping Countries Control Corruption. Washington, World Bank002E. 